Ocena wyników leczenia hormonem wzrostu polskich pacjentów z idiopatycznym niedoborem hormonu wzrostu (IGHD) i niedoborem hormonu wzrostu

z wspólistniejącymi zmianami organicznymi (OG HD) w wieku przedpokwitaniowym

- na podstawie bazy danych KIGS

\title{
Assessment of Results of Growth Hormone Therapy of Polish Patients with Idiopathic Growth Hormone Deficiency (IGHD) and Other Organic Growth Hormone Deficiency (OGHD)in Prebubertal Age - Data from Pfizer International Growth Study - KIGS
}

${ }^{1}$ Barbara Rymkiewicz-Kluczyńska, ${ }^{2}$ Borys Zarzycki

${ }^{1}$ Klinika Pediatrii i Endokrynologii, Warszawski Uniwersytet Medyczny; ${ }^{2}$ Bayer Sp. z 0.0.

Adres do korespondencji:

Barbara Rymkiewicz_Kluczyńska, ul. Stryjeńskich 19 m. 468, 02-791Warszawa, e-mail: barbara.rymkiewicz.kluczynska@gmail.com

Słowa kluczowe: niedobór hormonu wzrostu, leczenie hormonem wzrostu, szybkość wzrastania Key words: growth hormone deficiency, growth hormone therapy, height velocity

\section{STRESZCZENIE/ABSTRACT}

Wstęp. Leczenie pacjentów z somatotropinową niedoczynnością przysadki (SNP) preparatami hormonu wzrostu
ma na celu poprawę szybkości wzrastania (height velocity, HV), prowadzącą do osiągnięcia możliwie najlepsze-
go, zbliżonego do przewidywanego wzrostu ostatecznego (predicted adult height, PAH). Cel. Ocena wyników lecze-
nia hormonem wzrostu polskich pacjentów z idiopatycznym niedoborem hormonu wzrostu (IGHD) oraz niedoborem
hormonu wzrostu i współistniejącymi zmianami organicznymi (OGHD) w wieku przedpokwitaniowym w okresie
pierwszych trzech lat leczenia na podstawie bazy danych pacjentów KIGS. Pacjenci i metody. Badaniem objęto gru-
pę pacjentów z IGHD, która w momencie rozpoczęcia leczenia liczyła 179 dzieci, oraz grupę pacjentów z OGHD
- 47 dzieci. Analizowane parametry to: wiek chronologiczny (CA) w chwili rozpoczęcia leczenia, wysokość ciała (Ht)
w SDS, średni wzrost rodziców (MPH) w SDS, masa ciała urodzeniowa w SDS, BMI w SDS, szybkość wzrastania
(HV) w cm/rok przed rozpoczęciem leczenia i w kolejnych latach leczenia, stosowana dawka hormonu wzrostu w mg/
kg/tydz. Wszyscy pacjenci objęci leczeniem byli w okresie prepubertalnym. Niedobór hormonu wzrostu był ocenia-
ny na podstawie dwu testów stymulacyjnych. Wyniki. Średni wiek pacjentów w chwili rozpoczęcia leczenia w grupie 
IGHD i OGHD wynosił odpowiednio 8,6 vs. 8,31 lat; wysokość ciała (Ht) -3,28 SDS vs. -3,4 SDS; wysokość ciała w odniesieniu do śr. wzrostu rodziców (Ht-MPH) -2,44 SDS vs. -3,21 SDS; szybkość wzrastania (HV) 4,22 cm/rok vs. $4,02 \mathrm{~cm} / \mathrm{rok}$. Pacjenci w obu grupach otrzymywali podobne dawki GH (0,19 mg/kg/tydz. Szybkość wzrastania (HV) w pierwszym roku leczenia wynosiła odpowiednio $8,96 \mathrm{~cm} / \mathrm{rok}$ vs. 9,79 cm/rok. Wysokość ciała (Ht) po trzech latach leczenia wynosiła w grupie IGHD -2,18 SDS; w grupie OGHD -1,17 SDS. Wnioski. Odpowiedź wzrostowa w pierwszym roku leczenia GH ma zasadnicze znaczenie w prognozowaniu dalszego wzrastania. Wiek rozpoczęcia leczenia, wysokość ciała w chwili rozpoczęcia leczenia, średni wzrost rodziców oraz przyczyna niedoboru hormonu wzrostu mają ogromne znaczenie w odpowiedzi wzrostowej w pierwszym roku leczenia. Endokrynol. Ped. 12/2013;1(42):17-28.

Introduction. Patients with growth hormone deficiency are treated with recombinant growth hormone to improve their growth velocity and to achieve best results in height, as close as possible to predicted adult height. Aim. Assessment of results of first three years of growth hormone therapy of polish patients with idiopathic growth hormone deficiency (IGHD) and other organic growth hormone deficiency (OGHD)in prebubertal age. Based on data from Pfizer International Growth Study - KIGS. Patients and methods. There were a group of 179 children with idiopathic growth hormone deficiency and 47 with other organic growth hormone deficiency. Analyzed parameters: chronological age at GH start, height in SDS, mid-parental height in SDS, body weight in SDS at birth, BMI in SDS, height velocity before treatment and in first 3 years of therapy, GH dose. All the patients were prepubertal. Growth hormone deficiency were confirmed in two GH stimulating tests. Results. At GH start mean chronological age in IGHD and OGHD were 8.6 y vs. 8.31 y respectively, height: -3.28 SDS vs. -3.4 SDS respectively, Ht-MPH: -2.44 SDS vs. $-3.21 \mathrm{SDS}$ respectively, HV: 4,22 cm/y vs. $4.02 \mathrm{~cm} / \mathrm{y}$ respectively. Both groups received the same GH treatment: $0.19 \mathrm{mg} / \mathrm{kg} /$ week. HV after $1^{\text {st }}$ year of treatment were $8.96 \mathrm{~cm} /$ year vs. 9,79 cm/year respectively. Height after $3^{\text {rd }}$ year of treatment were -2,18 SDS and -1,17 SDS respectively. Conclusions. In the group of children in prepubertal age, response to $\mathrm{GH}$ treatment after $1^{\text {st }}$ year of therapy has got a significant implication to the prognosis of final results of GH therapy. Chronological age, height, mid-parental height and source of GH deficiency have got an impact on growth hormone response in $1^{\text {st }}$ year of therapy. Pediatr. Endocrinol. 12/2013;1(42):17-28.

\section{Wstęp}

Po raz pierwszy ekstrakcyjny przysadkowy hormon wzrostu w leczeniu dziecka niskorosłego z niedoborem hormonu wzrostu zastosował Raben ponad 50 lat temu [1]. W latach 80.h XX wieku do leczenia dzieci niskorosłych z niedoborem hormonu wzrostu wprowadzono rekombinowany ludzki hormon wzrostu (rGH).

Leczenie pacjentów z somatotropinową niedoczynnością przysadki (SNP) preparatami hormonu wzrostu ma na celu poprawę szybkości wzrastania (height velocity, $\mathrm{HV}$ ) prowadzącą do osiągnięcia możliwie najlepszego, zbliżonego do przewidywanego wzrostu ostatecznego (predicted adult height, PAH). Wzrost końcowy (ostateczny) pacjenta (finale height, FH) jest zależny od wielu czynników. Analiza danych bazy pacjentów Kabi International Growth Study (KIGS) wskazuje na istotne znaczenie w osiągnięciu optymalnego wzrostu końcowego następujących czynników: wysokości ciała rodziców (midparental height, MPH), wieku chronologicznego w chwili rozpoczęcie leczenia, niedoboru wysokości ciała w momencie rozpoczęcia leczenia wyrażonego w SDS, masy ciała urodzeniowej w SDS, maksymalnego wyrzutu GH w testach stymulacyjnych oraz całkowitej dawki hormonu wzrostu i czasu leczenia [2].
W latach 1992-2011 w Polsce leczono i udokumentowano jako część szerokiego badania farmakoepidemiologicznego KIGS 1229 pacjentów (ryc. 1-3). Badania KIGS były prowadzone zgodnie $\mathrm{z}$ deklaracją helsińską [3]. Największą grupę leczonych stanowiły dzieci z niedoborem hormonu wzrostu (Growth Hormone Deficiency, GHD), wśród których wyodrębniono zgodnie z klasyfikacją KIGS [4] pacjentów z idiopatycznym niedoborem hormonu wzrostu (Idiopathic Growth Hormone Deficiency, IGHD) [5] i pacjentów z niedoborem hormonu wzrostu z współistniejącymi zaburzeniami rozwojowymi osi podwzgórzowo-przysadkowej, jak hipoplazja przysadki, ,puste siodło”, centralne zaburzenia rozwojowe, postaci wrodzone (Other Growth Hormone Deficiency, OGHD).

\section{Cel pracy}

Celem badania była ocena odpowiedzi wzrostowej w trzech pierwszych latach leczenia hormonem wzrostu.

\section{Pacjenci i metody}

Z całej polskiej grupy KIGS z lat 1992-2011, liczącej 1229 pacjentów objęto badaniem grupę 179 


\section{Histogram}

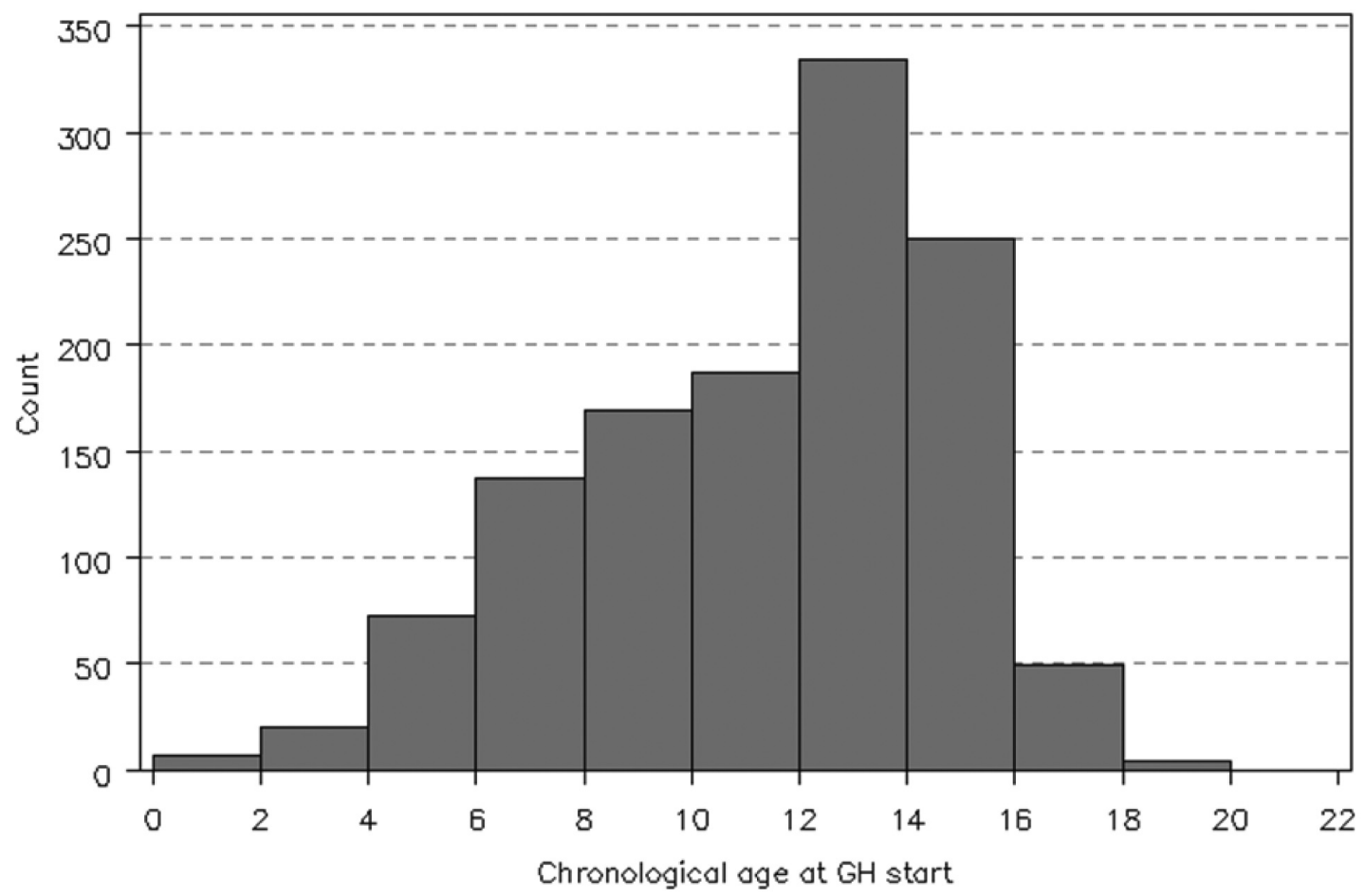

Ryc. 1. Wiek chronologiczny przed rozpoczęciem leczenia - cała populacja

Fig. 1. Chronological age at GH start - whole population

\section{Histogram}

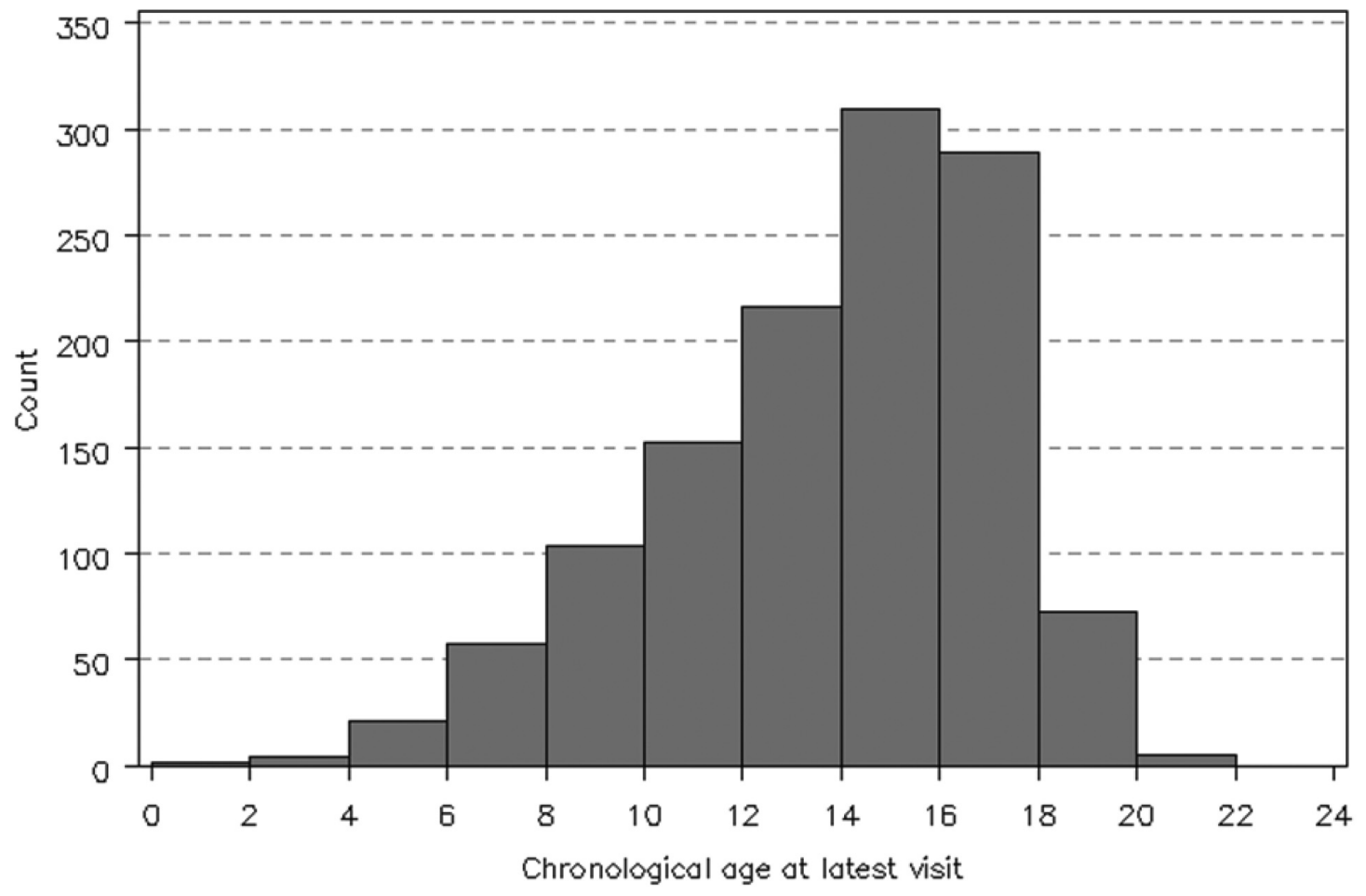

Ryc. 2. Wiek chronologiczny - ostatnia wizyta (zakończenie leczenia)

Fig. 2. Chronological age at latest visit (end of treatment) 


\section{Histogram}

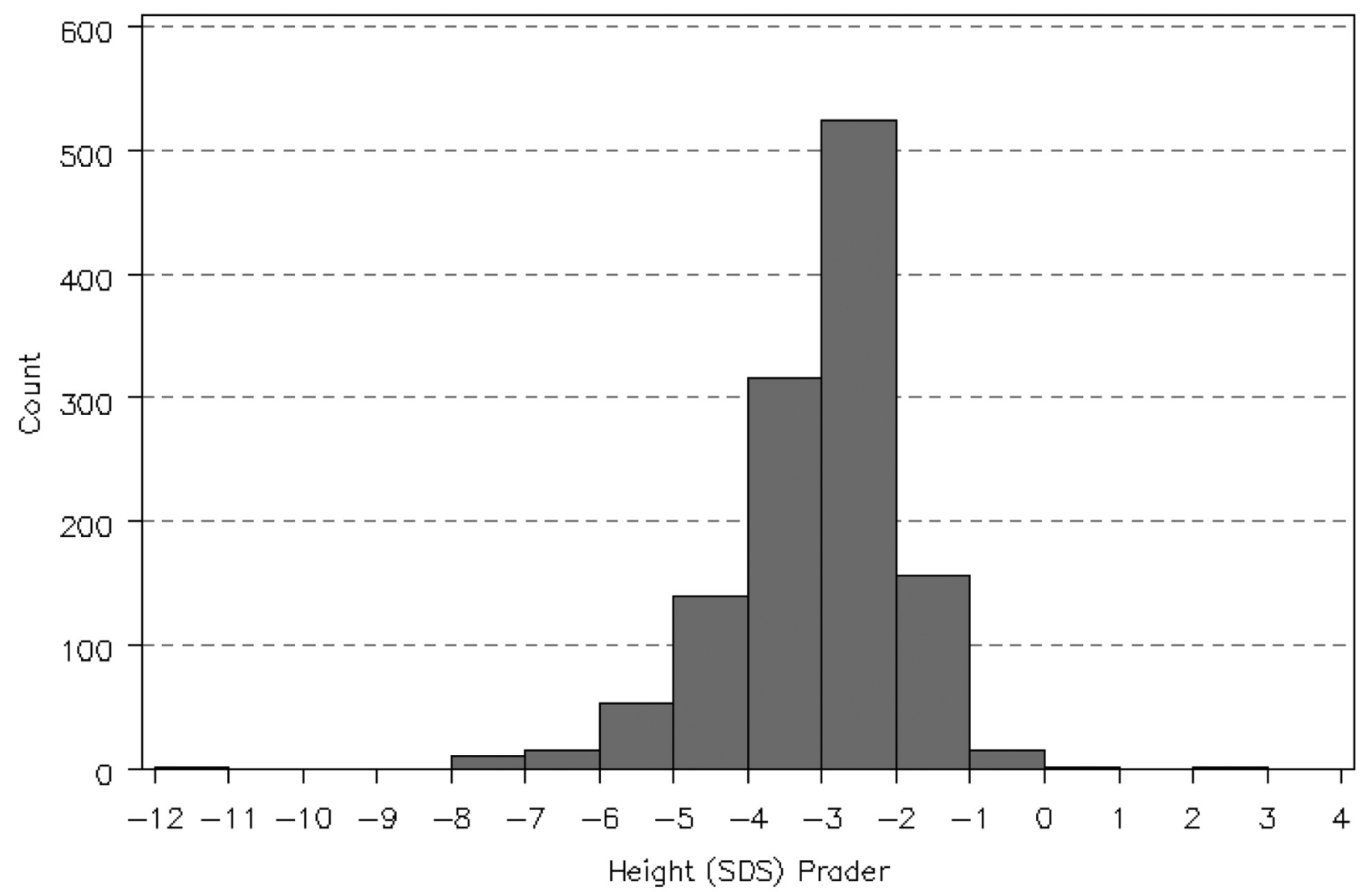

Ryc. 3. Wysokość ciała w SDS przed rozpoczęciem leczenia GH

Fig. 3. Height SDS at GH start

dzieci $\mathrm{z}$ idiopatycznym niedoborem hormonu wzrostu (IGHD) oraz grupę 47 dzieci z niedoborem hormonu wzrostu i stwierdzonymi zaburzeniami osi podwzgórzowo-przysadkowej (OGHD). Analizowane parametry to: wiek chronologiczny (CA) w chwili rozpoczęcia i zakończenia leczenia (ryc. 4, 5), wysokość ciała (Ht) w SDS (ryc. 6-10), średni wzrost rodziców (MPH) w SDS, różnica wysokości ciała do średniego wzrostu rodziców (Ht - MPH) wyrażona w SDS, masa ciała urodzeniowa w SDS, BMI w SDS, szybkość wzrastania (HV) $\mathrm{w} \mathrm{cm} /$ rok przed rozpoczęciem leczenia i w kolejnych latach leczenia, stosowana dawka hormonu wzrostu (mg/kg/tydz.) [6]. Pomiary wysokości ciała wykonywane w okresach 12 mies. \pm 3 mies. służyły do obliczenia Ht SDS, $\Delta$ Ht SDS i HV. Wysokość ciała pacjentów była oceniana w odniesieniu do aktualnych wartości referencyjnych dla dzieci polskich [7]. Pacjenci objęci badaniem byli w okresie prepubertalnym, w wieku do 11 r.ż.; u dziewczynek gruczoły piersiowe były w I stad. wg Tannera, u chłopców objętość jąder $<4 \mathrm{ml}$. Ponieważ po- przednie badania wykazywały, że wzrastanie w okresie przedpokwitaniowym jest niezależne od płci, dane dotyczące chłopców i dziewczynek były oceniane łącznie $[8,9]$. Niedobór hormonu wzrostu był oceniany na podstawie dwu testów stymulacyjnych, w których maksymalny wyrzut hormonu wzrostu wynosił $<10 \mathrm{ng} / \mathrm{ml}$.

W grupie pacjentów z idiopatycznym niedoborem hormonu wzrostu (IGHD) wyodrębniono pacjentów z izolowanym niedoborem hormonu wzrostu (ISNP) i wielohormonalną niedoczynnością przysadki (WNP) - tabela I. W grupie pacjentów z WNP było więcej chłopców $(66,7 \%)$ w porównaniu $z$ grupą ISNP (57,7\%); niedobór wysokości ciała $(\mathrm{Ht})$ był znaczniejszy w odniesieniu do grupy ISNP (-3,6 SDS vs -3,06 SDS); również różnica wysokości ciała do średniego wzrostu rodziców (Ht-MPH) była większa (-2,79 SDS vs -2,18 SDS); szybkość wzrastania (HV) mniejsza $(3,98 \mathrm{~cm} / \mathrm{rok}$ vs $4,25 \mathrm{~cm} / \mathrm{rok}$ ); maksymalne wyrzuty hormonu wzrostu w testach stymulacyjnych były niższe 3,35 $(0,7-9,14) \mathrm{ng} / \mathrm{ml}$ vs $5,75(1,55-8,98) \mathrm{ng} / \mathrm{ml}$. Bada 


\section{Histogram}

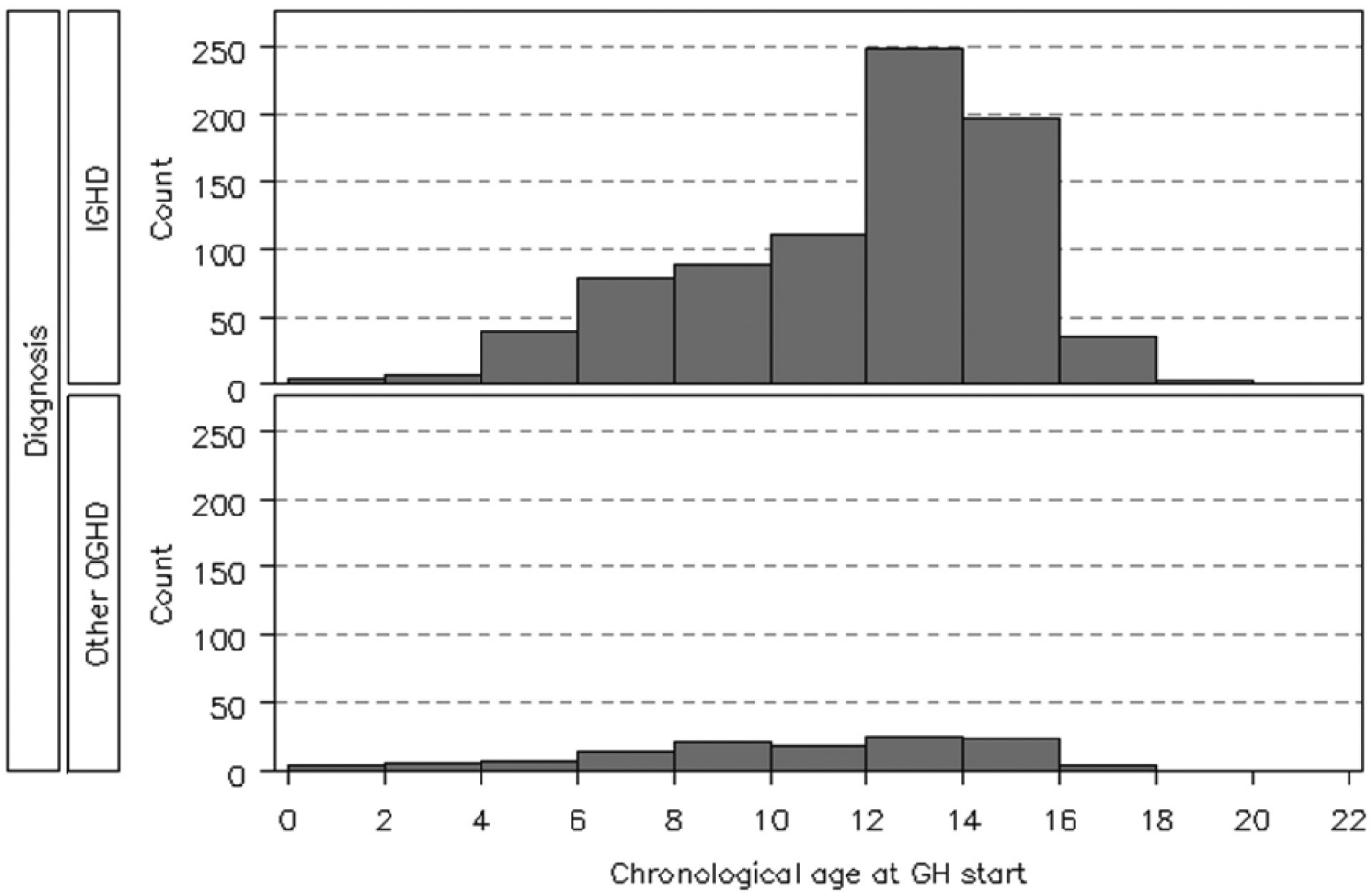

Ryc. 4. Wiek chronologiczny w momencie rozpoczęcia terapii GH - grupa IGHD oraz grupa OGHD Fig. 4. Chronological age at GH start IGHAD and OGHD group

\section{Histogram}

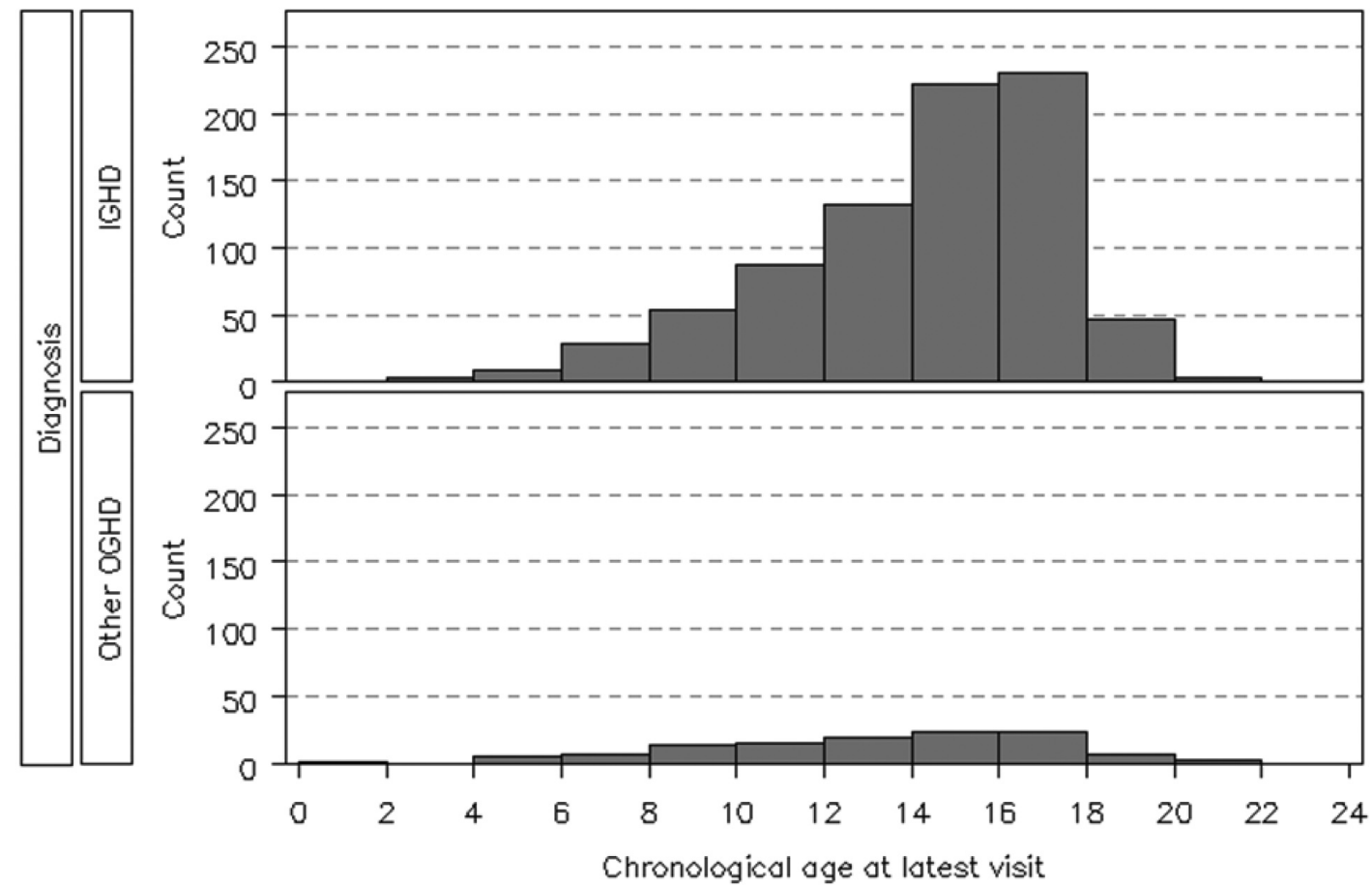

Ryc. 5. Wiek kalendarzowy - ostatnia wizyta: grupa IGHD oraz grupa OGHD Fig. 5. Chronological age at latest visit: IGHD and OGHD group 


\section{Histogram}

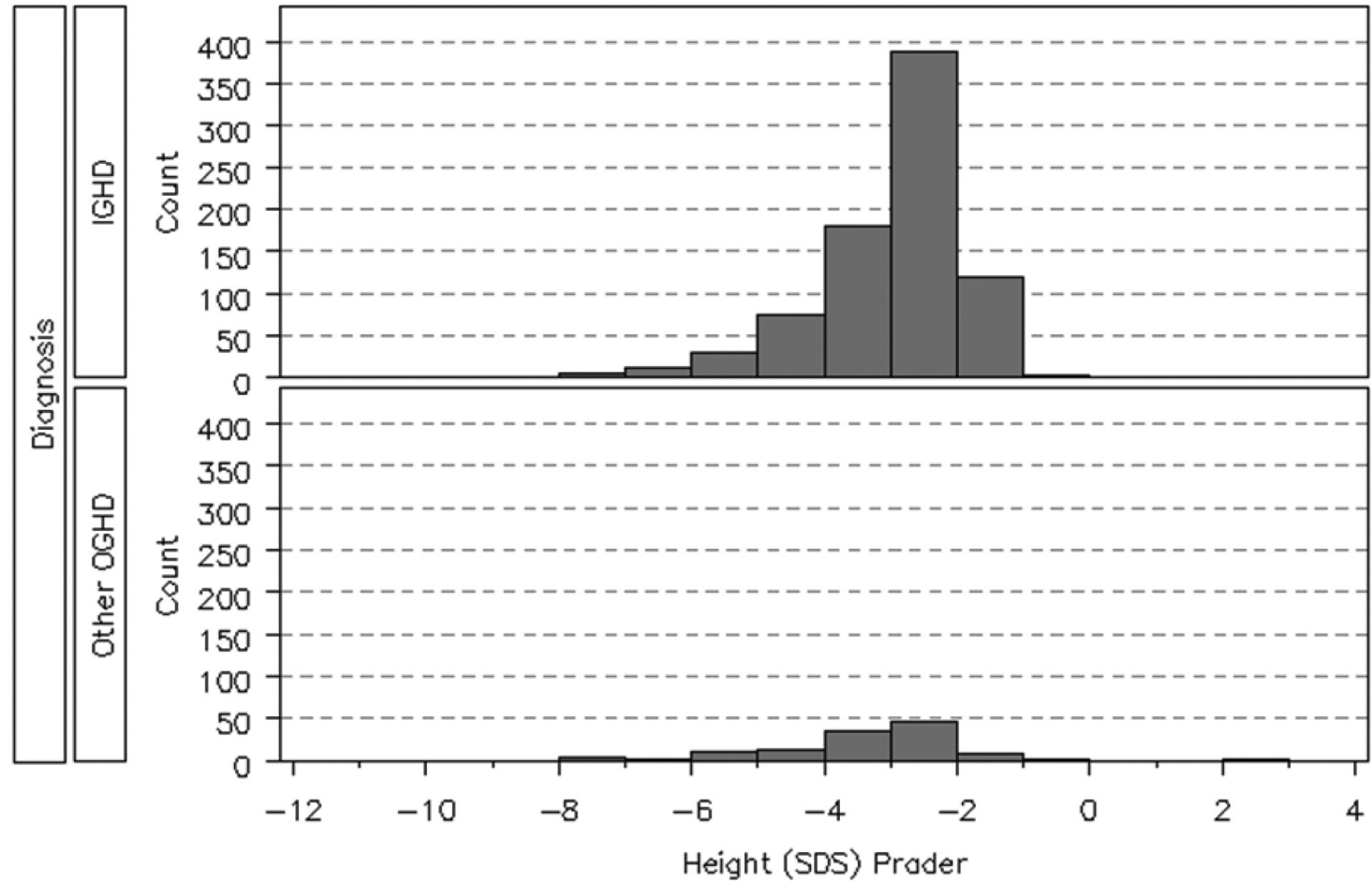

Ryc. 6. Wysokość ciała w SDS przed rozpoczęciem leczenia GH w grupie IGHD oraz grupie OGHD Fig. 6. Height SDS at GH start by Diagnosis: IGHD and OGHD

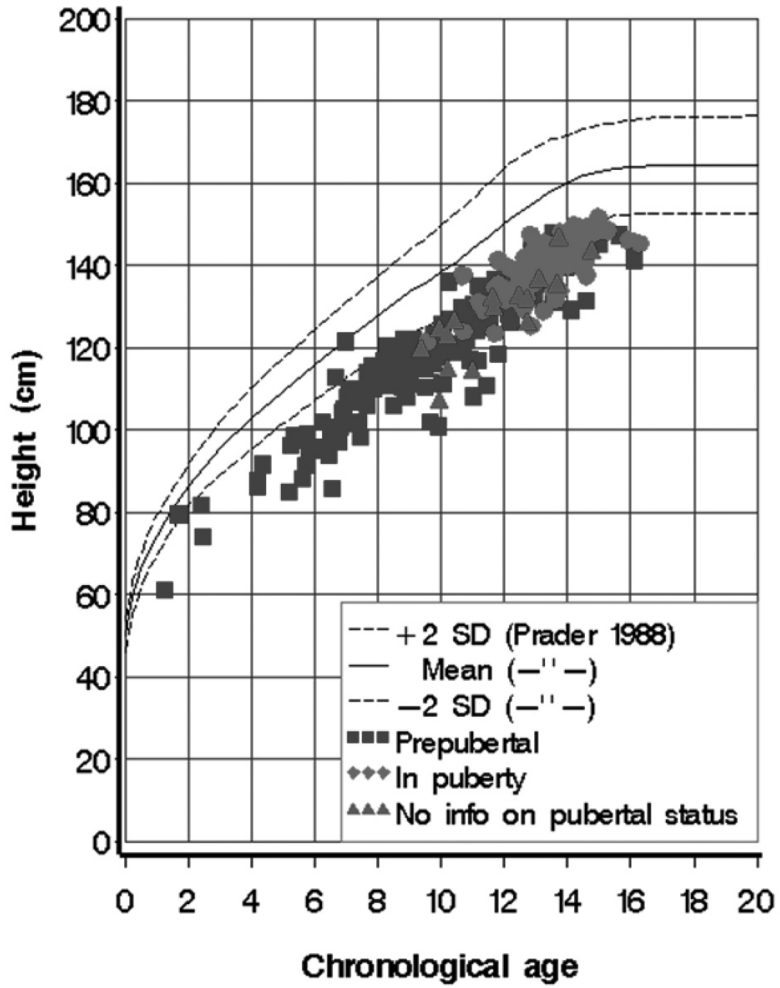

Ryc. 7. Wysokość ciała (cm) przed rozpoczęciem leczenia: IGHD dziewczęta

Fig. 7. Height at start of GH therapy IGHD Girls

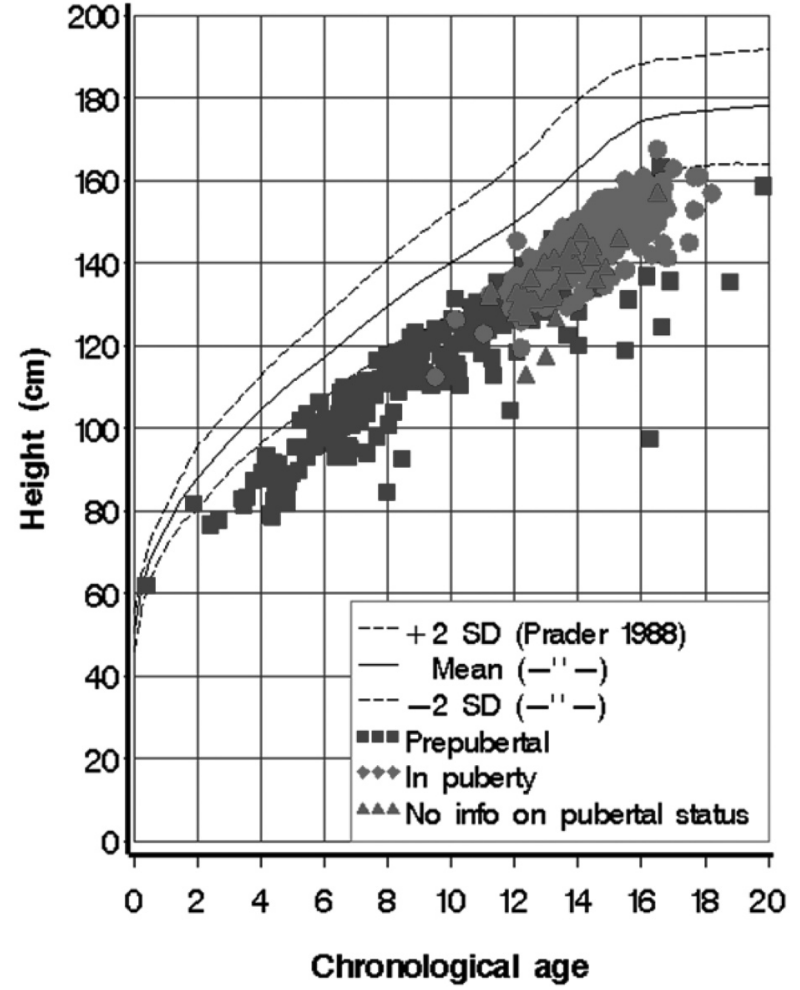

Ryc. 8. Wysokość ciała (cm) przed rozpoczęciem leczenia: IGHD chtopcy

Fig. 8. Height at start of GH therapy IGHD Boys 


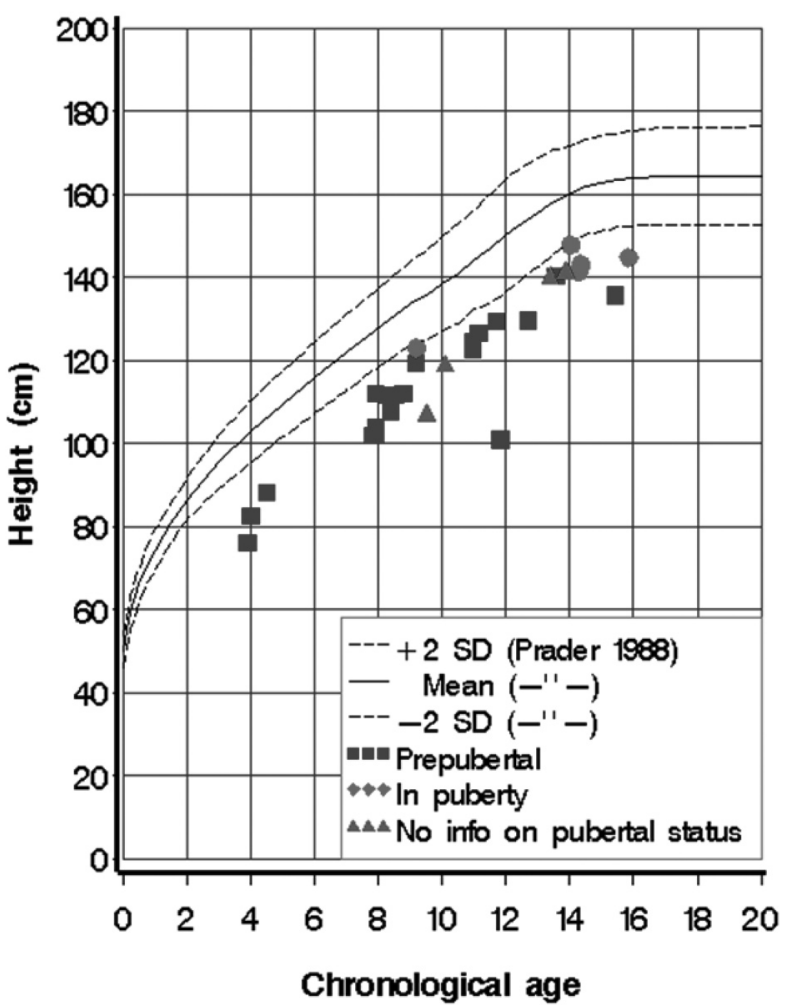

Ryc. 9. Wysokość ciała (cm) przed rozpoczęciem leczenia: OGHD dziewczęta

Fig. 9. Height at start of GH therapy Other OGHD Girls

na grupa pacjentów z niedoborem hormonu wzrostu i stwierdzonymi zaburzeniami osi podwzgórzowo-przysadkowej (OGHD) w wieku przedpokwitaniowym (tabela III) liczyła 47 osób, w tym 70\% stanowili chłopcy; wiek chronologiczny w chwili rozpoczęcia leczenia wynosił 8,31 lat; wysokość ciała (Ht) -3,40 SDS; wysokość ciała w odniesieniu do średniego wzrostu rodziców (Ht-MPH) -3,21 SDS; szybkość wzrastania (HV) -4,02 cm/rok.

\section{Wyniki}

Odpowiedź na leczenie hormonem wzrostu u pacjentów z IGHD w okresie przedpokwitaniowym w kolejnych trzech latach leczenia przedstawia tabela II. Średni wiek pacjentów w chwili rozpoczęcia leczenia hormonem wzrostu wynosił 8,6 lat; wysokość ciała (Ht) -3,28 SDS, a szybkość wzrastania (HV) 4,22 cm/rok. W okresie pierwszych dwu lat leczenia pacjenci otrzymywali podobne dawki hormonu wzrostu - 0,19 mg/kg/tydz. W trzecim roku leczenia przeciętna dawka wzrosła do $0,20 \mathrm{mg} /$ kg/tydz. Szybkość wzrastania (HV) w pierwszym roku leczenia wynosiła 8,96 cm/rok; w drugim 7,32 $\mathrm{cm} /$ rok, w trzecim $6,68 \mathrm{~cm} /$ rok. Niedobór wysokości ciała $\mathrm{w}$ pierwszym roku leczenia poprawił się

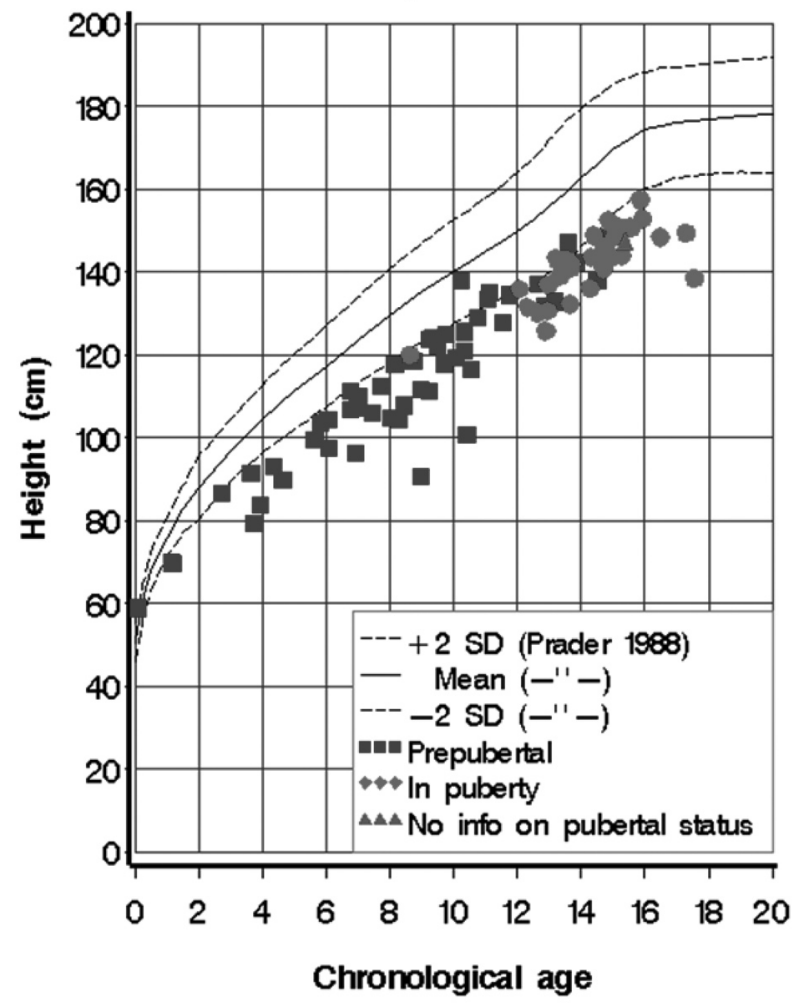

Ryc. 10. Wysokość ciała (cm) przed rozpoczęciem leczenia: OGHD chłopcy

Fig. 10. Height at start of GH therapy Other OGHD Boys

o 0,77 SDS, w drugim o 1,18 SDS, a po trzech latach o 1,7 SDS. Przeciętna wysokość ciała (Ht) po roku leczenia wynosiła $-2,49$ SDS; po dwu latach -2,22 SDS; po trzech latach -2,18 SDS.

W pierwszych dwu latach leczenia, podobnie jak w grupie z IGHD, pacjenci otrzymywali hormon wzrostu w dawkach $0,19 \mathrm{mg} / \mathrm{kg} / \mathrm{tydz}$; w trzecim roku leczenia 0,20 mg/kg/tydz. Szybkość wzrastania $(\mathrm{Ht})$ w pierwszym roku leczenia wynosiła 9,79 $\mathrm{cm} /$ rok. Niedobór wysokości ciała w pierwszym roku leczenia poprawił się o 0,99 SDS, w drugim o 1,91 SDS, a w trzecim o 2,77 SDS. Wysokość ciała $(\mathrm{Ht})$ po roku leczenia wynosiła $-2,36 \mathrm{SDS}$; po dwu latach 1,61 SDS; po trzech latach -1,17 SDS

Tabela IV zawiera wybrane parametry odpowiedzi wzrostowej u pacjentów z IGHD oraz OGHD w okresie leczenia hormonem wzrostu.

\section{Dyskusja}

Badania Reiter, Price i innych na podstawie analizy danych 1258 pacjentów z GHD w bazie KIGS potwierdzają wpływ czynników auksologicznych i stopnia niedoboru hormonu wzrostu na wyniki długofalowego leczenia hormonem wzrostu [10]. 
Tabela I. Charakterystyka pacjentów z idiopatycznym niedoborem hormonu wzrostu (IGHD) przed rozpoczęciem leczenia GH Table I. IGHD patients before GH therapy - characteristic

\begin{tabular}{|l|c|c|}
\hline & $\begin{array}{c}\text { A. ISNP } \\
(n-104)\end{array}$ & $\begin{array}{c}\text { B. WNP } \\
(n-74)\end{array}$ \\
\hline Chłopcy & $57,7 \%$ & $66,7 \%$ \\
m. ciała urodz. (SDS) & $-0,74$ & $-0,48$ \\
dt. ciała urodz. (SDS) & 1,01 & 1,24 \\
CA (lata) & 8,58 & 8,72 \\
Ht (SDS) & $-3,06$ & $-3,60$ \\
MPH (SDS) & $-0,94$ & $-1,14$ \\
Ht - MPH (SDS) & $-2,18$ & $-2,79$ \\
BMI (SDS) & $-0,38$ & $-0,33$ \\
HV (cm/rok) & 4,25 & 3,98 \\
Max $\uparrow$ GH (ng/ml) & 5,73 & 3,35 \\
& $(1,55-8,98)$ & $(0,7-9,14)$ \\
\hline
\end{tabular}

* Wartość w medianach, GH - hormon wzrostu, GHD - niedobór hormonu wzrostu, IGHD - idiopatyczny niedobór hormonu wzrostu, ISNP - izolowana, somatotropinowa niedoczynność przysadki, WNP - wielohormonalna niedoczynność przysadki

$\mathrm{CA}$ - wiek chronologiczny, $\mathrm{Ht}$ - wysokość ciała, MPH - średni wzrost rodziców, Ht - MPH - wysokość ciała w odniesieniu do średniego wzrostu rodziców, HV - szybkość wzrastania

Tabela II. Odpowiedź na leczenie GH pacjentów z IGHD w okresie przedpokwitaniowym - wybrane parametry w pierwszych trzech latach leczenia

Table II. Longitudinal data on the characteristics and parameters of response of prepubertal IGHD patients at start and during the first 3 years of GH therapy

\begin{tabular}{|l|c|c|c|c|}
\hline & $\begin{array}{l}\text { Przed rozpoczęciem } \\
\text { leczenia (n -179) }\end{array}$ & $\begin{array}{l}\text { Po I roku leczenia } \\
(\mathrm{n}-179)\end{array}$ & $\begin{array}{l}\text { Po II roku leczenia } \\
(\mathrm{n}-90)\end{array}$ & $\begin{array}{l}\text { Po III roku } \\
\text { leczenia } \\
(\mathrm{n}-37)\end{array}$ \\
\hline CA (lata) & 8,6 & 9,57 & 9,78 & 9,82 \\
Ht (SDS) & $-3,28$ & $-2,49$ & $-2,22$ & $-2,18$ \\
MPH (SDS) & $-1,06$ & $-1,06$ & $-1,10$ & $-0,80$ \\
Ht - MPH (SDS) & $-2,44$ & $-1,70$ & $-1,37$ & $-1,36$ \\
HV (cm/rok) & 4,22 & 8,96 & 7,32 & 6,68 \\
$\begin{array}{l}\text { Ht (SDS) } \\
\text { W danym roku }\end{array}$ & 0,77 & 0,42 & 0,33 \\
leczenia & & 0,77 & 1,18 & 1,70 \\
$\begin{array}{l}\text { Ht (SDS) } \\
\text { Od momentu } \\
\text { rozpoczęcia leczenia }\end{array}$ & & & & \\
$\begin{array}{l}\text { Dawka GH } \\
\text { (mg/kg/tydz.) }\end{array}$ & & 0,19 & 0,19 & 0,20 \\
\hline
\end{tabular}

* Wartość w medianach, CA - wiek chronologiczny, Ht - wysokość ciała, MPH - średni wzrost rodziców, Ht - MPH - wysokość ciała w odniesieniu do średniego wzrostu rodziców, HV - szybkość wzrastania, $\Delta \mathrm{Ht}$ - przyrost wysokości ciała 
Tabela III. Odpowiedź na leczenie GH pacjentów z niedoborem hormonu wzrostu i stwierdzonymi zaburzeniami rozwojowymi osi podwzgórzowo-przysadkowej (OGHD) w okresie przedpokwitaniowym - wybrane parametry w pierwszych trzech latach leczenia

Table III. Longitudinal data on the characteristics and parameters of response of prepubertal OGHD patients at start and during the first 3 years of GH therapy

\begin{tabular}{|l|c|c|c|c|}
\hline & $\begin{array}{c}\text { Przed rozpoczęciem } \\
\text { leczenia }(n-47)\end{array}$ & $\begin{array}{l}\text { Po I roku leczenia } \\
(n-47)\end{array}$ & $\begin{array}{l}\text { Po II roku leczenia } \\
(n-22)\end{array}$ & $\begin{array}{l}\text { Po III roku } \\
\text { leczenia }(n-10)\end{array}$ \\
\hline Chłopcy & $70 \%$ & & & 10,45 \\
CA (lata) & 8,31 & 9,27 & $-1,76$ & $-1,17$ \\
Ht (SDS) & $-3,40$ & $-2,36$ & $-0,93$ & $-0,93$ \\
MPH (SDS) & $-0,81$ & $-0,81$ & $-1,06$ & $-0,06$ \\
Ht - MPH (SDS) & $-3,21$ & -172 & 8,16 & 7,22 \\
HV (cm/rok) & 4,02 & 9,79 & 0,73 & 0,43 \\
$\Delta$ Ht (SDS) & & 0,99 & 1,91 & 2,77 \\
W danym roku leczenia & & 0,99 & & 0,20 \\
$\Delta$ Ht (SDS) & & 0,19 & 0,19 & 0,20 \\
Od momentu rozpoczęcia leczenia & & & \\
Dawka GH (mg/kg/tydz.) & &
\end{tabular}

* Wartości medianach

Tabela IV. Charakterystyka i wybrane parametry odpowiedzi wzrostowej u pacjentów z IGHD i OGHD w okresie przedpokwitaniowym w chwili rozpoczęcia leczenia i w okresie 3 lat leczenia hormonem wzrostu

Table IV. Longitudinal data on the characteristics and parameters of response of prepubertal IGHD and OGHD patients at start and during the first 3 years of GH therapy - comparison

\begin{tabular}{|l|c|c|}
\hline & IGHD $(n-179)$ & OGHD $(n-47)$ \\
\hline Przed rozpoczęciem leczenia GH & & \\
Wiek CA (lata) & 8,6 & 8,31 \\
Ht (SDS) & $-3,28$ & $-3,40$ \\
HV (cm/rok) & 4,22 & 4,02 \\
Po roku leczenia & & \\
Ht (SDS) & $-2,49$ & $-2,36$ \\
HV (cm/rok) & 8,96 & 9,79 \\
$\Delta$ Ht (SDS) & 0,77 & 0,99 \\
dawka GH (mg/kg/tydz.) & 0,19 & 0,19 \\
Po dwu latach leczenia & & \\
Ht (SDS) & $-2,22$ & $-1,61$ \\
HV (cm/rok) & 7,32 & 8,16 \\
$\Delta$ Ht (SDS) & 1,18 & 1,91 \\
dawka GH (mg/kg/tydz.) & 0,19 & 0,19 \\
Po trzech latach leczenia & & \\
Ht (SDS) & $-2,18$ & $-1,17$ \\
HV cm/rok) & 6,68 & 7,22 \\
$\Delta$ Ht (SDS) & 1,70 & 2,77 \\
dawka GH (mg/kg/tydz.) & 0,20 & 0,20 \\
\hline
\end{tabular}


Ranke M i wsp. stworzyli matematyczny model odpowiedzi na leczenie hormonem wzrostu u dzieci w okresie przedpokwitaniowym z IGHD [11]. U pacjentów z IGHD szybkość wzrastania w pierwszym roku leczenia może być prognozowana na podstawie algorytmu uwzględniającego wiek pacjenta, wysokość ciała w odniesieniu do średniego wzrostu rodziców, masy ciała, masy ciała urodzeniowej, niedoboru hormonu wzrostu i stosowanej dawki hormonu wzrostu [12]. Średni wzrost rodziców, który określa potencjał genetyczny dziecka, jak i odpowiedź wzrostowa w pierwszym roku leczenia jest miarą wrażliwości na hormon wzrostu. Odpowiedź wzrostowa w pierwszym roku leczenia w prognozowaniu dalszego wzrastania w kolejnych latach leczenia i osiągnięciu optymalnego wzrostu końcowego ma zasadnicze znaczenie. W kolejnych latach leczenia pacjentów w okresie przedpokwitaniowym ważnym prognostykiem dalszego wzrastania są masa ciała, wiek, dawka hormonu wzrostu i szybkość wzrastania w roku poprzedzającym leczenie [13-15]. Wysokość ciała (Ht-SDS) w pierwszym roku leczenia, jak i w całym okresie przedpokwitaniowym ma wysoką korelację z całkowitym przyrostem wysokości ciała w okresie leczenia hormonem wzrostu. Na wielkość całkowitego przyrostu wysokości ciała mają również wpływ: wiek rozpoczęcia leczenia, maksymalne wyrzuty GH w testach stymulacyjnych, wysokość ciała $\mathrm{w}$ chwili rozpoczęcia leczenia, średni wzrost rodziców i czas trwania terapii (16).

Na podstawie obszernego badania obejmującego ponad 5000 pacjentów w okresie przedpokwitaniowym z GHD z KIGS-Pfizer International Growth Database, Ranke i wsp. oceniali szybkość wzrastania $\mathrm{HV} \mathrm{cm} /$ rok i $\Delta$ Ht SDS w pierwszym i drugim roku leczenia hormonem wzrostu, porównywali również wyniki otrzymane na podstawie bazy danych i otrzymane w modelu predykcji [12].

Porównując wyniki badanej grupy polskiej i międzynarodowej KIGS należy zauważyć, że w chwili rozpoczęcia leczenia dzieci $\mathrm{w}$ grupie polskiej były starsze (w latach) IGHD - 8,6,OGHD - 8,31 vs. grupa międzynarodowa $\mathrm{w}$ zależności od niedoboru GH max GH $<5 \mathrm{mg} / \mathrm{ml}-6,44$, max GH $5-10$ $\mathrm{mg} / \mathrm{ml}-6,86$; wysokość ciała wynosiła odpowiednio $\mathrm{w}$ grupach polskich i międzynarodowych $-\mathrm{Ht}$ SDS $(-3,28 ;-3,4$ vs. $-3,6 ;-3,19)$; szybkość wzrastania $\mathrm{HV} \mathrm{cm/rok}(4,22 ; 4,02$ vs. 5,$0 ; 5,07)$.
Pacjenci w grupie międzynarodowej otrzymywali większą dawkę hormonu wzrostu $(0,22 \mathrm{mg} / \mathrm{kg} /$ tydz. vs. $0,19 \mathrm{mg} / \mathrm{kg} / \mathrm{tydz}$.). Szybkość wzrastania (HV cm/rok) w pierwszym roku leczenia $\mathrm{w}$ grupie międzynarodowej z większym niedoborem GH wynosiła 10,3, z mniejszym niedoborem GH - 8,58; w polskiej grupie odpowiednio - IGHD - 8,96; OGHD - 9,76, a przyrost wysokości ciała $(\Delta \mathrm{Ht}$ SDS) w grupie międzynarodowej 1,11 i $0,74 \mathrm{w}$ zależności od niedoboru GH; w grupie polskich dzieci IGHD -0,77; OGHD -0,99. Różnice te można thumaczyć wiekiem rozpoczęcia leczenia, stopniem niedoboru hormonu wzrostu i stosowaną dawką hormonu wzrostu w poszczególnych grupach. W badaniach europejskich przeciętna stosowana dawka hormonu wzrostu wynosiła $0,18 \mathrm{mh} / \mathrm{kg} /$ tydz.; dawki stosowane w USA były większe - 0,3 $\mathrm{mg} / \mathrm{kg} / \mathrm{tydz}$.

Podobne wyniki wzrastania sugerują, że dawki hormonu wzrostu mają ograniczony wpływ na wzrastanie, chociaż większe dawki hormonu wzrostu mogą we wczesnym okresie leczenia zwiększać catch up wzrostu. Całkowita dawka hormonu wzrostu w okresie przedpokwitaniowym może być ważnym czynnikiem poprawiającym wzrost końcowy [14-19].

Zastosowanie modelu indywidualnej prognozy wzrostowej wskazuje na dużą zmienność osobniczą odpowiedzi na hormon wzrostu. Wskazane jest dostosowanie indywidualnej dawki hormonu wzrostu w leczeniu dzieci z GHD w okresie przedpokwitaniowym. Wiek rozpoczęcia leczenia ma ogromne znaczenie w odpowiedzi wzrostowej w pierwszym okresie leczenia.

\section{Wnioski}

Odpowiedź wzrostowa w pierwszym roku leczenia GH u pacjentów z niedoborem hormonu wzrostu $\mathrm{w}$ okresie przedpokwitaniowym ma zasadnicze znaczenie $\mathrm{w}$ prognozowaniu dalszego wzrastania w kolejnych latach leczenia i osiągnięciu optymalnego wzrostu końcowego. Wiek rozpoczęcia leczenia, wysokość ciała w chwili rozpoczęcia leczenia, średni wzrost rodziców oraz przyczyna niedoboru hormonu wzrostu grają główną rolę w odpowiedzi wzrostowej w pierwszym roku leczenia. 
[1] Raben M.S.: Treatment of a pituitary dwarf with human growth hormone J. Clin. Endocrinol. Metab., 1958:18, 901-903.

[2] Cutfield W.S., Lindberg A., Chatelain P., Price D.A., Albertson-Wikland K., Wilton .P, Ranke MB on behalf of the KIGS International Board: Final Height Following Growth Hormone Treatment of Idiopathic Growth Hormone Deficiency in KIGS; Growth Hormone Therapy - 10 Years' Experience. Heidelberg, Leipzig: Barth, 1999, 93-109.

[3] World Medical Association 2008, The Declaration of Helsinki http://www.wma.net/en/20cvctivities/10ethnics/10helsinki/index.html

[4] KIGS advanced patient outcome; Etiology classification List Pfizer Endocrine care Stockholm 2002.02.20.

[5] Cutfield W.S., Karagiannis G., Reiter E.0.: Growth Hormone Treatment to Final Height in Idiopathic Growth Hormone Deficiency: The KIGS Experience Growth Hormone Therapy in Pediatrics - 20 Years of KIGS. Basel, Karger, 2007, 145-162.

[6] Romer T.E., Walczak M., Wisniewski A. et al.: Children with growth disorders qualified in Poland for growth hormone therapy. Pediatria Praktyczna, 2001:9, 41-54.

[7] Palczewska I., Niedźwiecka Z.: Wskaźniki rozwoju somatycznego dzieci I młodzieży warszawskiej. Medycyna Wieku Rozwojowego, 2001:5, Suppl. I do $\mathrm{nr}$ 2, 17-118.

[8] Ranke M.B., Price D.A., Albertsson-Wikland K., Maes M., Lindberg A., on behalf of the International Board of the Kabi Pharmacia Intern. Growth Study: Factors Determining Pubertal Growth and Final Height in Growth Hormone Treatment of Idiopathic Growth Hormone Deficiency. Horm Res, 1997:48, 62-71.

[9] Tanner J.M., Whitehouse R.H.: Clinical longitudinal standards for height, weight, height vecolity, weight velocity and stages of puberty. Arch. Dis. Child., 1976:51, 170-179.

[10] Reiter E.O., Price D.A., Wilton P., Albertsson-Wikland K., Ranke M.B.: Effect of Growth Hormone (GH) Treatment on the Near Final Height of 1258 Patients with Idiopathic GH Deficiency: Analysis of a Large International Database. J. Clin. Endocrinol. Metab., 2006: 91, 2047-2054.

[11] Ranke M.B., Lindberg A., Chatelain P., Wilton P., Cuttield W., Albertsson-Wikland K., Price D.A.: Derivation and validation of a mathematical model for predicting the response to exogenous recombinant human growth hormone (GH) in prepubertal children with idiopathic GH deficiency. KIGS International Board Kabi Pharmacia International Growth Study. J. Clin. Endocrinol. Metab., 1999:84, 1174-1183.

[12] Ranke M.B., Lindberg A., on behalf of the KIGS Int Board: Observed and Predicted Growth Responses in Prepubertal Children with Growth Disorders: Guidance of Growth Hormone Treatment by Empirical Variables. J. Clin. Endocrinol. Metab., 2010:95, 1229-1237.

[13] Hilczer M., Smyczyńska J., Stawerska R., Lewiński A.: Ocena auksologicznych wskaźników skuteczności leczenia hormonem wzrostu dzieci z somatotropinową niedoczynnością przysadki w zależności od wydzielania hormonu wzrostu przed rozpoczęciem terapii. Endokrynologia pediatryczna, 2005:4, nr 3(12), 31-38.

[14] Ranke M.B., Lindberg A., Martin D.D., Baker B. et al.: The mathematical model for total pubertal growth in idiopathic growth hormone (GH) deficiency suggests a moderate role of GH dose. J. Clin. Endocrinol. Metab., 2003:88, 4748-4753.

[15] Hilczer M., Smyczyńska J., Lewiński A.: Ocena skuteczności leczenia hormonem wzrostu dzieci z somatotropinową niedoczynnością przysadki na podstawie poprawy tempa wzrastania i wydzielania insulinopodobnego czynnika wzrostowego w pierwszym roku terapii. Endokrynologia Pediatryczna, 2006:5, nr 1(14), 9-14.

[16] Westphal 0., Lindberg A.: On behalf of the Swedish KIGS National Bard Final height in Swedish children with idiopathic growth hormone deficiency enrolled in KIGS treated optimally with growth hormone. Acta Paediatrica, 2008:97, 1698-1706.

[17] Ranke M.B., Lindberg A., KIGS International Board: Observed and predicted total pubertal growth (TPG) during treatment with growth hormone in adolescents with idiopathic growth hormone deficiency (GHD), Turner syndrome (TS), short stature born small for idiopathic short stature (ISS). KIGS analysis an review. Horm. Res. Ped., 2011:75, 423-432.

[18] Mac Gillivray M.H., Blethen S.L., Buchlis J.G. et al.: Current dosing of growth hormone in children with growth hormone deficiency: how physiologic? Pediatrics, 1998:102 (Suppl 2), 527-530.

[19] Ranke M.B., Reiter E.0., Price D.A.: Idiopathic Growth Hormone Deficiency in KIGS: Selected Aspects Growth Hormone Therapy in Pediatrics - 20 Years of KIGS Basel. Karger 2007, 116-135. 